\title{
Penggunaan Model Blended Learning terhadap Hasil Belajar di masa Pandemi Covid-19
}

\author{
Handy Ferdiansyah ${ }^{1}$, Zulkifli N ${ }^{2}$, Rahman Yakub ${ }^{3}$, Agussalim $^{4}$ \\ 123 (Bisnis Digital/ UniversitasMuha mmadiyah Sidenreng Rappang). \\ ${ }^{4}$ (Teknologi Pendidikan/UniversitasMuhammadiyah Sidenreng Rappang). \\ ** Corresponding Authors. E-mail: ${ }^{1}$ handyferdiansyah888@gmail.com \\ 2 zulkiflin73@gmail.com,rahman12@gmail.com ${ }^{3}$, agussalimagus51@gmail.com4
}

Receive: 13/05/2021

Accepted: 23/08/2021

Published: 01/10/2021

\begin{abstract}
Abstrak
Penelitian bertujuan untuk mengetahui tingkat kebutuhan penggunaan model Blended learning terhadap hasil belajar dimasa pandemi Covid 19. Jenis ini merupakan penelitian kuantitatif. Teknik pengumpulan data yang digunakan adalah teknik observasi dan angket kuesioner. Hasil penelitian ini menunjukkan bahwa penggunaan model Blended learning terhadap hasil belajar dimasa pandemi Covid 19: (i) menggambarkan perlunya penggunaan model Blended learning terhadap hasil belajar dimasa pandemi Covid 19 berawal dari himbauan pemerintah akan pelaksanaan Work From Home (ii) penggunaan model Blended learning terhadap hasil belajar dimasa pandemi Covid 19 dilihat dari hasil kuisioner yang telah dibagikan selanjutnya diolah dan dianalisis masuk kedalam kategori Sangat Praktis.
\end{abstract}

Kata Kunci: Model, blended learning, covid 19

\section{Abstract}

This study aims to determine the level of need for the use of the Blended learning model on learning outcomes during the Covid 19 pandemic. This type of research is a quantitative study. Data collection techniques used are observation techniques and questionnaires. The results of this study indicate that the use of the Blended learning model on learning outcomes during the Covid 19 pandemic: (i) illustrates the need for the use of Blended learning models on learning outcomes during the Covid 19 pandemic starting from the government's call for the implementation of Work From Home (ii) the use of Blended learning models for learning outcomes during the Covid 19 pandemic seen from the results of the questionnaires that have been distributed are then processed and analyzed into the Very Practical category.

Keywords: Model, blended learning, Covid-19 



\section{Pendahuluan}

Peningkatan mutu pendidikan merupakan hal wajib semua negara termasuk Negara Republik Indonesia yang merupakan salah satu di antara sekian banyaknya negara maju, Saat ini ditengah pandemi Covid 19 Indonesia kini sedang giat-giatnya melaksanakan pengembangan di segala bidang, baik sektor pertanian, pembangunan, kesehatan, maupun pendidikan.

Harus diakui bahwa pada bidang pendidikan di Indonesia hingga saat ini boleh dikatakan belum optimal, baik dalam hal desain, pengembangan, pemanfaatan, pengelolaan, maupun evaluasi. Sumber Daya Manusia (SDM) yang mengelola pendidikan harus memiliki kemampuan akademis dan profesional yang handal guna untuk mengembangkan dan/atau mengaplikasikan teknologi pendidikan agar penyelenggaraan pendidikan menjadi lebih berkualitas, efektif, efisien, dan relevan dengan kebutuhan dan tuntutan zaman (Elihami, 2017).

Terkait dengan tujuan pengembangan di negara kita lebih terarah untuk mewujudkan masyarakat yang adil dan makmur yang merata baik material dan spiritual berdasarkan landasan pancasila dan landasan konstitusional Undang-Undang Dasar 1945.

Tujuan pembangunan seperti tercantum dalam Garis-garis Besar Haluan negara tersebut di atas, jelas bahwa upaya pembangunan di negara kita tidak sematamata ditunjukkan kepada aspek-aspek yang bersifat fisik saja melainkan diarahkan sekaligus pada pembangunan yang menyangkut semua aspek kehidupan, yakni lahiriah dan jasmaniah. Salah satu aspek yang menunjang lajunya pembangunan tersebut adalah bidang pendidikan. Dengan pembangunan dalam bidang pendidikan maka akan mempercepat laju pembangunan dalam segala aspek bidang, termasuk bidang ekonomi, sosial politik, agama dan sebagainya. Pendidikan mempunyai peranan yang sangat penting dalam kemajuan suatu bangsa dan negara, baik negara maju maupun negara berkembang seperti layaknya Indonesia (Ferdiansyah, 2021).

Sejak

merebaknya

wabah

Coronavirus Disease (Covid-19) di Indonesia, pemerintah mengambil langkah pencegahan penyebaran virus tersebut. Di bidang pendidikan, langkah pencegahan yang ditempuh yakni pelaksanaan proses belajar dari rumah (BDR) seperti tertuang pada Surat Edaran Nomor 4 tahun 2020.

Semua tingkatan pendidikan mulai dari pendidikan anak usia dini, menengah, atas hingga perguruan tinggi mengambil kebijakan untuk melakukan pembelajaran di rumah dengan secara online/daring. Dengan mewabahnya virus Covid-19 yang menyebabkan berlakunya kebijakan Work From Home (WFH). Sehingga sekolah dan kampus secara nasional harus mengambil langkah dengan melaksanakan pembelajaran dengan sistem online/daring serta menerapkan Kurikulum Merdeka Belajar Kampus Merdeka, hal tersebut dilakukan untuk meningkatkan mutu pendidikan di masa pandemi ini.

Kurikulum Merdeka Belajar - Kampus Merdeka ini merupakan kebijakan Menteri Pendidikan dan Kebudayaan, yang bertujuan mendorong mahasiswa untuk menguasai berbagai keilmuan yang berguna untuk memasuki dunia kerja. Kampus Merdeka memberikan kesempatan bagi mahasiswa untuk memilih mata kuliah yang akan mereka ambil. Dalam hal ini Perguruan Tinggi baik negeri maupun swasta harus turut ambil bagian untuk menyukseskan tersebut.

Sebelum Program Merdeka Belajar Kampus Merdeka ini, Universitas Muhammadiyah Sidenreng Rappang telah turut ambil bagian dalam program pemerintah yaitu program pertukaran mahasiswa melalui kerjasama antara perguruan tinggi seIndonesia atau yang lebih dikenal dengan PERMATA SAKTI. Program Permata Sakti ini berlangsung pada tahun 2020 di awal masa pandemi Covid 19 di Indonesia hingga berlanjut pada penerapan Kurikulum Merdeka Belajar - Kampus Merdeka.

Diawal masa pandemi Covid 19 dimana beberapa perguruan tinggi negeri maupun 
swasta melakukan lockdown atau libur total, UMS Rappang tetap melakukan PBM. Proses pembelajaran dilakukan dengan sistem bleanded learning.

Blended learning merupakan strategi pembelajaran yang dapat mengembangkan kemampuan berpikir kritis dan mewadahi siswa untuk mengoptimalkan pemanfaatan informasi dan teknologi dan untuk meningkatkan hasil belajar. Blended learning merupakan pembelajaran yang menggabungkan pembelajaran tatap muka dan online. Blended learning juga dikenal sebagai pembelajaran hibrida. Istilah ini mengandung pengertian campuran, percampuran, atau gabungan dari belajar (Nurhikmah, 2018).

Ketika kita melakukan pembelajaran secara online tentunya kita memerlukan media sebagai sarana untuk pembelajaran. Oleh sebab itu berbagai Platfrom digunakan sebagai media pembelajaran oleh sekolah dan juga Universitas. Di Universitas sendiri terdapat berbagai platfrom yang digunakan di antaranya Google Classroom, Zoom Meeting, Whatsapp, Google Meet, dan sebagainya (Haqien, 2020)

Pelaksanaan pembelajaran dengan model Blended learning di Universitas Muhammadiyah Sidenreng Rappang memadukan aplikasi Zoom Meating dengan Open Learning. Aplikasi zoom meating merupakan salah satu aplikasi komunikasi video berbasis cloud computing buatan perusahaan Amerika. Aplikasi ini menyediakan layanan konferensi jarak jauh dengan menggabungkan konferensi video, pertemuan online, obrolan, hingga kolaborasi seluler (Latifah, 2020)

Aplikasi tersebut dapat diakses melalui sistem operasi baik itu windows, linux, ios, OS mac, website, maupun android. Aplikasi zoom memiliki berbagai fitur yang juga dapat digunakan dalam proses pembelajaran seperti meeting \& chat, video webinar, conference rooms, phone system, dan marketplace merupakan salah satu kelebihan yang membuat aplikasi ini banyak digunakan sebagai sarana belajar mengajar (Kelana, 2021).
Aplikasi ini tidak hanya dipakai pada kegiatan pembelajaran semata, melainkan pula dapat dipakai untuk kegiatan perkantoran bahkan kegiatan lainnya. Platfrom ini gratis jadi dapat digunakan oleh siapapun dengan batas waktu empat puluh menit dan tidak ada batasan waktu jika akun kita berbayar. Dalam aplikasi Zoom Meeting ini kita bisa berkomunikasi langsung dengan siapapun lewat video. Oleh karena itu, memang cocok digunakan sebagai media pembelajaran (Far-Far, 2021).

Sedangkan Open learning adalah platform pembelajaran online yang melampaui pengiriman konten untuk fokus pada masyarakat, keterhubungan, dan keterlibatan siswa. Open learning adalah sistem belajar mengajar jarak jauh, baik Dosen maupun mahasiswa dapat melaksanakan perkuliahan secara online, kapan saja dan dimana saja, tidak terbatas oleh jarak dan waktu. Materi/bahan pembelajaran di sajikan dalam berbagai media, salah satunya dengan video.

Setidaknya dengan penggunaan aplikasi open learning dapat menjawab semua atau beberapa tantangan dan kesulitan yang terjadi di masa pandemi Covid 19. Sebagai perguruan tinggi swasta yang memiliki visi menjadi perguruan tinggi yang Unggul, Professional Islami, dan mampu berperan aktif dalam pembangunan bangsa melalui proses pendidikan, penelitian dan pengabdian pada masyarakat.

Setelah melakukan observasi dan didukung oleh beberapa teori penulis tertarik untuk meneliti permasalahan tersebut ke dalam sebuah penelitian yang berjudul: "Efektivitas penggunaan model Blended learning terhadap hasil belajar dimasa pandemi Covid 19".

1. Bagaimana gambaran tingkat kebutuhan penggunaan model Blended learning terhadap hasil belajar dimasa pandemi Covid 19?

2. Bagaimana tingkat kepraktisan penggunaan model Blended learning terhadap hasil belajar dimasa pandemi Covid 19? 


\section{Metode}

Penelitian ini bertujuan mendeskripsikan data tentang penggunaan model Blended learning terhadap hasil belajar pengantar bisnis dimasa pandemi Covid 19 dikalangan mahasiswa. Untuk itu, pendekatan yang digunakan adalah kuantitatif deskriptif dengan metode survei ke lapangan/lokasi penelitian berdasarkan teknik pengumpulan data melalui wawancara dengan penyebaran instrumen (kuesioner) kepada responden.

Metode survei merupakan metode riset dengan menggunakan kuesioner sebagai instrumen pengumpulan datanya. Tujuannya untuk memperoleh informasi tentang sejumlah responden yang dianggap mewakili populasi tertentu. Dalam survei proses pengumpulan dan analisis data sosial bersifat sangat terstruktur dan mendetail melalui kuesioner sebagai instrumen utama untuk mendapatkan informasi dari sejumlah responden yang diasumsikan mewakili populasi yang spesifik. Teknik analisis data deskriptif bertujuan untuk mencari dan mendeskripsikan fenomena yang terjadi masyarakat tanpa bermaksud mencari hubungan antara variabel satu dengan variabel lain (Sugiyono, 2009: 35).

Populasi dalam penelitian ini adalah akademisi dan civitas di Fakultas Ekonomi dan Bisnis yang berjumlah 51 orang dimana mahasiswa program studi kewirausahaan sebanyak 13 sedangkan mahasiswa program studi bisnis digital sebanyak 38. Pada penelitian ini peneliti menggunakan teknik purposive sampling dimana pengambilan sampel yang berdasarkan atas suatu pertimbangan tertentu seperti sifat-sifat populasi ataupun ciri-ciri yang sudah diketahui sebelumnya (Notoatmodjo 2018:14). Berdasarkan teori tersebut sehingga peneliti berinisiatif untuk menarik sampling yakni mahasiswa program studi bisnis digital.

Subjek pada penelitian ini adalah akademisi atau dosen mata kuliah pengantar bisnis pada prodi bisnis digital fakultas ekonomi dan bisnis Universitas Muhammadiyah Sidenreng Rappang yaitu bapak Zulkifli N, S.Pd., M.Pd. dan DR. Jamaluddin, S.Sos., M.Si. serta mahasiswa program studi Bisnis Digital 38 (tiga puluh delapan) orang. Objek pada penelitian adalah penggunaan model Blended learning terhadap hasil belajar dimasa pandemi Covid 19.

Namun berhubungan dengan tujuan penelitian yakni ingin mengetahui tingkat kebutuhan dan kepraktisan penggunaan model Blended learning terhadap hasil belajar dimasa pandemi Covid 19, sehingga digunakan instrumen. Instrumen yang akan diuji coba adalah lembar angket kepraktisan penggunaan model Blended learning terhadap hasil belajar dimasa pandemi Covid 19. Adapun ujicoba yang akan dilaksanakan meliputi uji kepraktisan.

Pada tahap uji tingkat kepraktisan, dosen dan mahasiswa dilibatkan sebagai responden yang akan menjadi penilai pada proses penelitian ini. Respon atau penilaian diperlukan langsung dari dosen dan mahasiswa selaku responden untuk memperoleh data yang akan dijadikan sebagai dasar guna untuk mengetahui tingkat kepraktisan model Blended learning terhadap hasil belajar dimasa pandemi Covid 19.

Seluruh data yang didapatkan dari responden diolah dan dianalisis menggunakan menggunakan rumus sebagai berikut:

\section{Persentase $=\frac{\sum(\text { jawaban } \mathrm{x} \text { bobot tiap pilihan })}{n \times \text { bobot tertinggi }} \times$ $100 \%$}

Sumber: Arismunandar, (2015)

Selanjutnya akan ditarik kesimpulan untuk menetukan tingkat

\section{Tabel 1}

Tingkat pencapaian dan kriteria produk

\begin{tabular}{lll}
\hline No & $\begin{array}{l}\text { Tingkat } \\
\text { pencapaian }\end{array}$ & Kriteria \\
\hline 1 & $81 \%-100 \%$ & Sangat praktis \\
\hline 2 & $61 \%-80 \%$ & Praktis \\
\hline 3 & $41 \%-60 \%$ & Cukup praktis \\
\hline
\end{tabular}




\begin{tabular}{|c|c|}
\hline 4 & $21 \%-40 \%$ \\
\hline & $0 \%-20 \%$ \\
\hline Sumb & er: Akbar (2017) \\
\hline
\end{tabular}

Peneliti mengambil tempat penelitian di Universitas Muhammadiyah Sidenreng Rappang. Salah satu perguruan tinggi swasta yang berada dibawah naungan yayasan Muhammadiyah. Lokasi beralamatkan di Jl. Angkatan 45 A1 Lautang Salo kel Maccorawalie kec. Pancarijang kab. Sidenreng Rappang, Sulawesi-Selatan. Peneliti sendiri melakukan observasi dan pengamatan, menemukan bahwa pembelajaran masih tatap muka sehingga dikhawatirkan penyebaran Covid 18. Karena pelaksanaan proses pembelajaran yang masih dilaksanakan di dalam ruang kelas dengan metode ceramah sedikit ice breaking tanpa adanya media pelatihan yang berbasis teknologi sedangkan sekarang sudah masuk di era sociality 5.0 ditengah wabah Covid 19. Penelitian ini dilaksanakan pada bulan April tahun 2020 sampai dengan bulan Juni tahun 2020.

Selama proses penelitian peneliti melakukan observasi serta sedikit wawacanra dengan beberapa dosen mata kuliah dan mahasiswa untuk mengetahui seberapa besar tingkat kebutuhan penggunaan model bleanded learning di Universitas Muhammadiyah Sidenreng Rappang ditengah wabah Covid 19.

\section{Pembahasan}

Penggunaan model Blended learning terhadap hasil belajar dimasa pandemi Covid 19 di Universitas Muhammadiyah Sidenreng Rappang khususnya pada mata kuliah pengantar bisnis, berawal dari analisis terhadap kebutuhan dosen dan mahasiswa. Observasi dilaksanakan pada 1 April 2020. Berdasarkan dari hasil observasi lapangan tersebut ditemukan jika selama ini proses pembelajaran dosen menyampaikan materi pembelajaran masih kurang memaksimalkan teknologi yang ada ditambah lagi kurang mematuhi protokol kesehatan. Para peserta didik dalam hal ini mahasiswa dinilai masih kurang antusias dalam mengikuti perkuliahan.

Kondisi ini membuat mereka memberikan gagasan melalui kuesioner yang telah disebar tersebut dengan kesimpulan jika perkuliahan akan lebih aman dan menyenangkan jika penggunaan model Blended learning sehingga dosen dan mahasiswa merasa lebih inovatif serta interaktif sesuai dengan perkembangan zaman dan kondisi saat ini.

Selain dari memenuhi himbauan pemerintah akan ketaatan terhadap protokol kesehatan, WFH juga terlaksana. Oleh karena itu, inovasi pada dunia pendidikan sangat diperlukan menjawab dan menghadapi tantangan yang ada dan yang akan datang. Mereka membutuhkan pembaharuan bukan cuma pada teknologi saja akan tetapi model pembelajaran yang diterapkan juga harus sesuai dengan mata kuliah serta kondisi yang terjadi di lapanagan.

Salah satu model pembelajaran yang tepat yaitu model pembelajaran bleanded learning. Dimana pada proses pelaksanaannya dosen memadukan aplikasi openlearning dan zoom meating. Saat sekarang ini model bleanded learning mulai mengambil perhatian banyak pihak, baik dari kalangan akademik, industri, profesional, maupun perusahaan. Bleanded learning merupakan salah satu model pembelajaran yang dapat digunakan baik pada ranah pendidikan keluarga ataupun lingkungan sekitar. Saat ini Bleanded learning dapat dikatakan sebagai salah satu solusi akan kondisi pendidikan saat ini dan sudah banyak peneliti yang memberikan bukti empiris terkait penggunaan model Blended learning dalam proses pembelajaran. Pengunaan Blended learning dalam proses pembelajaran pengantar bisnis, dosen bisa mengatur jadwal pada aplikasi open learning selanjutnya mengkolaborasikan dengan zoom meating. Untuk mahasiswa yang ketinggalan pada jadwal mata kuliah pengantar bisnis tersebut, tetap bisa mengikuti perkuliahan hingga batas waktu yang telah ditentukan oleh dosen pengampuh mata kuliah via video recorder 
yang telah diinput pada aplikasi Open learning.

Dosen (pendidik) bekerja dengan mempersiapkan bahan ajar/materi untuk keperluan proses perkuliahan. Akan tetapi dosen bisa menyelesaikan seluruh materi hingga soal MID dan Final selanjutnya menginput pada aplikasi Open learning.

Akibatnya dosen juga memiliki waktu lebih untuk melakukan penelitian dan pengabdian kepada masyarakat. Ditinjau dari segi kebutuhan tersebut dan didukung bukti empirisnya maka diketahui gambaran kebutuhan penggunaan model Blended learning terhadap hasil belajar dimasa pandemi Covid 19.

Kepraktisan penggunaan model Blended learning terhadap hasil belajar dimasa pandemi Covid 19 yang peroleh dari hasil analisis lembar penilaian dosen dan penilaian mahasiswa. Pada hasil penilaian mahasiswa terhadap penggunaan model Blended learning terhadap hasil belajar dimasa pandemi Covid 19 khususnya mata kuliah pengantar bisnis dan berdasarkan tabel 1 mengenai konversi skor, diketahui bahwa rata-rata skor mencapai $92 \%$. termasuk dalam kategori "Sangat praktis" untuk digunakan.

Kesimpulannya, penggunaan model Blended learning terhadap hasil belajar dimasa pandemi Covid 19 termasuk dalam kategori "Sangat Praktis".

\section{Kesimpulan}

Gambaran kebutuhan akan
penggunaan model Blended learning terhadap hasil belajar dimasa pandemi Covid 19 khususnya pada mata kuliah pengantar bisnis berawal dari kondisi atau situasi pandemi Covid 19 serta adanya berbagai aturan dari pemerintah akan Work From Home proses pembelajaran menggunakan model Bleanded Learning memang sudah selayaknya diterapkan. Karena selain dari himbauan dari pemerintah, pemerintah juga sangat mendukung dengan adanya pembagian kouta gratis baik dosen maupun mahasiswa
Penggunaan model Blended learning terhadap hasil belajar dimasa pandemi Covid 19 memenuhi kriteria kepraktisan berdasarkan penilaian dari dosen dan mahasiswa dengan kategori Sangat Praktis.

\section{Daftar Pustaka}

[1] Arismunandar \& Nurhikmah H. 2015. Pengembangan Model Pelatihan Mbs Bagi Kepala Sekolah. Proceeding. Scientific Forum-Faculty of Education Departement of Science Education (FIP-JIP) and The International Seminar.

[2] Elihami, E. (2016). Meningkatkan Hasil Belajar Al-Islam Dan Kemuhammadiyahan Melalui Kuis Dengan Umpan Balik Pada Mahasiswa Kelas. SAFINA: Jurnal Pendidikan Agama Islam, 1(2), 27-37.

[3] Far-Far, G. (2021). Efektifitas Penggunaan Aplikasi Zoom Meeting Dalam Pembelajaran Di Masa Pandemi Covid-19. ISTORIA: Jurnal Pendidikan dan Sejarah, 17(1).

[4] Ferdiansyah, H., Haling, A., \& Nurhikmah, H. (2021). Pengembangan Multimedia Interaktif dalam Pembelajaran Simulasi dan Komunikasi Digital. Indonesian Journal of Learning Education and Counseling, 3(2), 148-155.

[5] Haqien, D., \& Rahman, A. A. (2020). Pemanfaatan zoom meeting untuk proses pembelajaran pada masa pandemi covid-19. SAP (Susunan Artikel Pendidikan), 5(1).

[6] Kelana, J. B., Wulandari, M. A., \& Wardani, D. S. (2021). Penggunaan Aplikasi Zoom Meeting di Masa Pandemi Covid-19 Pada Pembelajaran Sains. Jurnal Elementary: Kajian Teori Dan Hasil 
Penelitian Pendidikan Sekolah Dasar, 4(1), 18-22.

[7] Latifah, L. (2020). Apa Itu Aplikasi Zoom? Alternatif Rapat Jarak Jauh, Begini Cara Kerjanya. TRIBUNNEWS.

[8] Nurhikmah, H., Tahmir, S., Junda, M., \& Bena, B. A. N. (2018, June). Blended Learning Media in Biology Classroom. In Journal of Physics: Conference Series (Vol. 1028, No. 1, p. 012027). IOP Publishing.

[9] Notoatmodjo, S (2018). Metodologi Penelitian Kesehatan. Jakarta: Rineka Cipta.

[10] Pusdiklat Kemdikbud. (2020). SURAT EDARAN MENDIKBUD NO 4 TAHUN 2020 TENTANG PELAKSANAAN KEBIJAKAN PENDIDIKAN DALAM MASA DARURAT PENYEBARAN CORONA VIRUS DISEASE (COVID- 1 9) - Pusdiklat Pegawai Kementerian Pendidikan dan Kebudayaan.

Https://Pusdiklat.Kemdikbud.Go.Id/.

[11] Sugiyono. 2013. Metode Penelitian Pendidikan Pendekatan Kuantitatif,. Kualitatif, dan R\&D. Bandung: Alfabeta

\section{Profil Penulis}

Penulis pertama yaitu Handy Ferdiansyah, S.Pd., M.Pd. penulis lahir di Ujung Pandang, 01 Januari 1988. Menetap di Sidereng Rappang. Pendidikan Sarjana (S1) ditempuh penulis di Sekolah Tinggi Keguruan dan Ilmu Muhammadiyah Rappang Program Studi Teknologi Pendidikan. Pada jenjang Magister (S2), penulis melanjutkan pendidikan di Universitas Negeri Makassar dengan prodi Teknologi Pendidikan. Saat ini penulis tercatat sebagai dosen di Universitas Muhammadiyah Sidenreng Rappang.
Penulis kedua Zulkifli N, S.Pd., M.Pd. penulis lahir di Ciro-ciroe, 27 juni 1993. Pendidikan sarjana ditempuh penulis di Sekolah Tinggi Keguruan dan Ilmu Muhammadiyah Rappang Program Studi Teknologi Pendidikan dan selesai pada tahun 2016. Pada jenjang magister, penulis melanjutkan pendidikan di Universitas Negeri Makassar dengan prodi Teknologi Pendidikan selesai pada tahun 2020. Saat ini penulis tercatat sebagai dosen di Universitas Muhammadiyah Sidenreng Rappang.

Penulis ketiga yaitu Rahman Yakub, S.T., M.AP. penulis lahir di Rappang, 4 Januari 1978. Pendidikan sarjana ditempuh penulis di Universitas Muslim Indonesia Program Studi Teknik dan Manajemen Industri Fakultas Teknik Industri. Pada jenjang magister, penulis melanjutkan pendidikannya di Universitas Muhammadiyah Sidenreng Rappang dengan prodi Administrasi Publik. Saat ini penulis berdomisili di Pangkajenne Kec. Maritenggae kab. Sidenreng Rappang.

Penulis keempat yaitu Drs. $\mathrm{H}$. Agussalim, M.Si. penulis lahir di Bone, 17 Agustus 1958. Pendidikan sarjana ditempuh penulis di Universitas Negeri Makassar selanjutnya Program Pascasarjana di Universitas Hasanuddin Saat ini penulis berdomisili di kota Makassar. 